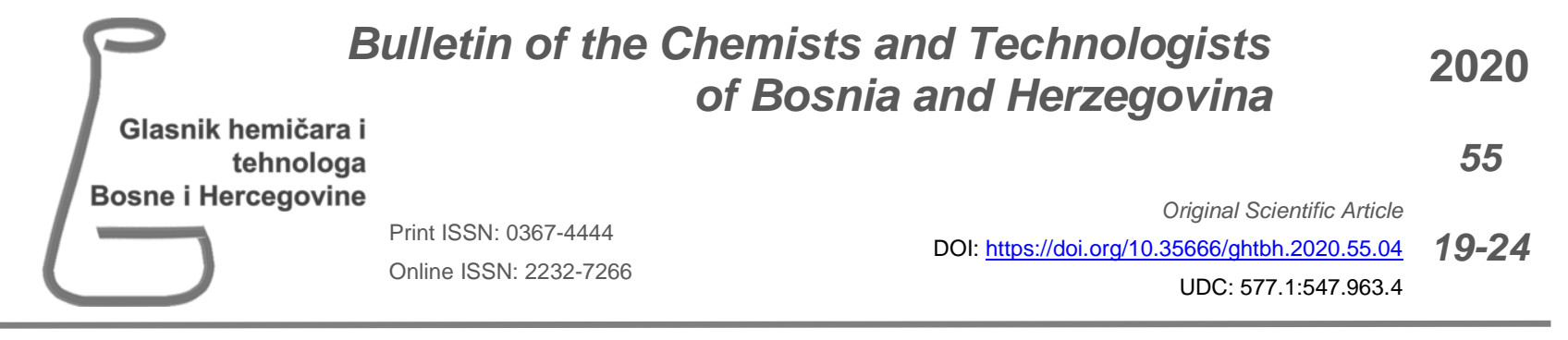

\title{
Peroxidase activity of hemoglobin and heme destruction in the presence of hydrogen peroxide and CT-DNA
}

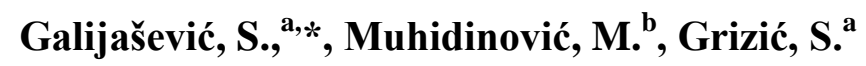 \\ ${ }^{a}$ Sarajevo School of Science and Technology, Sarajevo Medical School, Sarajevo, Bosnia and Herzegovina \\ ${ }^{b}$ L'UFR de Chimie, Sorbonne Université, Paris, France
}

\begin{abstract}
Article info
Received: 10/08/2020

Accepted: 21/10/2020
\end{abstract}

\section{Keywords: \\ hemoglobin \\ heme \\ peroxidase \\ oxidative stress}

\author{
* Corresponding author: \\ Semira Galijasevic \\ E-mail: semira.galijasevic@ssst.edu.ba \\ Phone: 00 387-61-410-878
}

\begin{abstract}
The aim of this study was to investigate the peroxidase activity of $\mathrm{Hb}$ with different concentrations of hydrogen peroxide and compare it with hypochlorous acid effect on $\mathrm{Hb}$. Hypochlorous acid at higher concentrations decomposed $\mathrm{Hb}$ and heme, releasing fee iron ion from the metal center. High concentrations of hydrogen peroxide switched the peroxidase activity of $\mathrm{Hb}$ towards the partial $\mathrm{Hb}$ and heme destruction. Heme alone was degraded showing that the $\mathrm{Hb}$ conformation and protein environment protects $\mathrm{Hb}$ from the distraction in the presence of highly increased hydrogen peroxide concentration that occurs as a result of oxidative stress. In the presence of CT-DNA acted inhibition of the peroxidase activity of $\mathrm{Hb}$ was observed signaling inhibited hydrogen peroxide consumption.
\end{abstract}

\section{INTRODUCTION}

Hemoglobin $(\mathrm{Hb})$ has an important role in human body as the oxygen-carrying metalloprotein, transporting oxygen from the lungs to the organs, cells, and tissues, where it releases $\mathrm{O}_{2}$. The oxygenation and deoxygenation processes are highly controlled by the allosteric regulation with the relaxed (R) state between with the high oxygen affinity, and the tense (T) state having the low oxygen affinity, (Schechter, 2008) In addition to its mayor role as oxygen carrier, $\mathrm{Hb}$ also performs a number of other functions in biological systems. Hemoglobin is involved in nitric oxide and bicarbonate transport, neutrophile degranulation process, blood coagulation, regulation of a blood pressure, renal absorption, cellular oxidant detoxification and hydrogen peroxide catalytic process. As an example, deoxy-Hb can also show, under defined reaction condition, a nitrite reductase activity thus been involved in compensatory vasodilation in connection with nitric oxide regulation. A heme (ferroprotoporphyrin IX) is a prostetic group of a number of heme proteins and is noncovalently bonded with each subunit in the space created between the helices in the hydrophobic pocket. The protoporphyrin IX consists of four pyrrole rings linked in a heterocyclic ring system. The $\mathrm{Fe}$ (II) is coordinated to the four nitrogen groups of protoporphyrin. The nitrogen atom of proximal histidine is coordinated to the iron from the bottom of the plane and the molecular oxygen binds to the iron on the opposite side.

Despite its significant biological role, under condition of oxidative stress, $\mathrm{Hb}$ can become toxic if it is released from erythrocytes. (Rifkind, Mohanty, Nagababu, 2015). This toxicity appeared to be caused by oxidative reactions catalyzed by $\mathrm{Hb}$ molecule. As a result, damage to surrounding tissues including biomolecules such as proteins, nucleic acids and lipids occurs (Alayash, Patel, Cashon, 2001). One of the reasons for the hemoglobin toxicity is its susceptibility to oxidation and autoxidation reactions. (Nagababu, Rifkind, 2004). In addition, in the presence of oxidative stress (i.g. high production of free radicals and hydrogen peroxide), heme metal center from hemoglobin is released in the surrounding environment generating more reactive oxygen species and, depending on the reaction condition, releasing free $\mathrm{Fe}(\mathrm{II})$. Free $\mathrm{Fe}(\mathrm{II})$ is sequestered and stored in ferritin through the tight control of ferritin synthesis in response to cellular iron status. Under extreme conditions, heme destruction is initiated, and excess of free iron is released in the surrounding environment, catalyzing the further formation of free radicals and amplifying host tissue damage (Nagababu, Chrest, Rifkind, 2003). Free Fe(II) can cause vasodilation and as result hypotension and metabolic acidosis will occurs. 
Iron damage to mitochondria by lipid peroxidation pathway results in renal and hepatic damage. (Ong, Halliwell, 2004; Trinder, Fox Vautier et al., 2002). The major source of hydrogen peroxide in the physiological system is the cellular respiratory burst that generates reactive oxygen species (ROS). This is oxygen dependent process where membrane-bound NADPH oxidase, catalyzes the reduction of molecular oxygen to the reactive oxygen intermediate, superoxide that in the presence of superoxide dismutase (SOD) produces hydrogen peroxide $\left(\mathrm{H}_{2} \mathrm{O}_{2}\right)$. Other source of hydrogen peroxide productions in the endothelium are vascular NADPH oxidase, xanthine oxidase (XO), uncoupled endothelial nitric oxide synthase (eNOS) and mitochondrial overproduction of reactive oxygen species. $\mathrm{Hb}$ reacts with low $\mathrm{H}_{2} \mathrm{O}_{2}$ concentrations producing Compound II $\left(\odot \mathrm{HbFe}^{4+}=\mathrm{O}\right)$ (Reactions 1, 2, 3, ).

$$
\begin{aligned}
& \mathrm{HbFe}^{2+} \mathrm{O}_{2}+\mathrm{H}_{2} \mathrm{O}_{2} \rightarrow \mathrm{HbFe}^{4+}=\mathrm{O}+\mathrm{H}_{2} \mathrm{O}+\mathrm{O}_{2} \\
& \mathrm{HbFe}^{4+}=\mathrm{O}+\mathrm{e}^{-}+2 \mathrm{H}^{+} \rightarrow \mathrm{HbFe}^{3+}+\mathrm{H}_{2} \mathrm{O} \\
& \mathrm{HbFe}^{3+}+\mathrm{H}_{2} \mathrm{O}_{2} \rightarrow \text { e } \mathrm{HbFe}^{4+}=\mathrm{O}+\mathrm{H}_{2} \mathrm{O}
\end{aligned}
$$

Increased hydrogen peroxide concentration can occur in biological systems during various inflammatory events. Endogenous $\mathrm{H}_{2} \mathrm{O}_{2}$ produced by neutrophils also has an important role in microbial killing. Less is known that bacteria can also produce $\mathrm{H}_{2} \mathrm{O}_{2}$ that has an effect on host-microbial interactions. For example, streptococci, pneumococci and lactobacilli due to the structural components-flavoproteins, use molecular oxygen to convert to hydrogen peroxide. Catalase is not present in these microbes, allowing accumulation of hydrogen peroxide. It is known that $S$. pneumoniae infection causes increased production of $\mathrm{H}_{2} \mathrm{O}_{2}$, up to millimolar concentration (Loose, Hudel, Zimmer, et al. 2015; Pericone, Parck, Imlay, et al., 2003).

Produced hydrogen peroxide then can serve as a substrate for the number of heme proteins or can be directly sequestered by $\mathrm{Hb}$ and incite the heme destruction and free $\mathrm{Fe}(\mathrm{II})$ release. Thus, knowing exact mechanism of heme release from hemoglobin and its activity in the presence of different concentrations of $\mathrm{H}_{2} \mathrm{O}_{2}$ is important since it can explain its determinant role in biological systems especially during the increased oxidative stress. Here we studied the reaction between human $\mathrm{Hb}(\mathrm{oxy}-\mathrm{Hb})$ with increasing hydrogen peroxide concentrations using spectroscopic methods. We examined the reaction between heme and hydrogen peroxide using spectroscopic method and electrophoresis. Since hypochlorous acid $(\mathrm{HOCl})$ is a strong oxidant and antimicrobial agent in the biological systems that can oxidized a number of biological molecules inflicting host tissue injury, we analyzed the reactions of $\mathrm{Hb}$ and heme with different $\mathrm{HOCl}$ concentrations. As control, Calf thymus DNA (CTDNA) was used to test whether it can mitigate toxicity caused by degradation of $\mathrm{Hb}$ or heme.

\section{EXPERIMENTAL}

\section{Chemicals}

All chemicals used were of the highest purity grade and used without further purification. Sodium hypochlorite $(\mathrm{NaOCl})$ heme, human hemoglobin ( $\mathrm{Hb})$, dimethylsulfoxide (DMSO), CT-DNA were obtained from Sigma Aldrich (St. Louis, MO, USA).

\section{Absorbance measurements.}

The absorbance spectra were recorded using Thermofisher Biosystems UV-visible spectrophotometer at $25^{\circ} \mathrm{C}$, and in phosphate buffer at $\mathrm{pH}$ 7.2. Fixed concentrations of $\mathrm{Hb}$ and heme were prepared and increasing concentration of $\mathrm{H}_{2} \mathrm{O}_{2}$ added to the solution (10-400 $\mu \mathrm{M})$. Absorbance spectra were then recorded from 300 to $700 \mathrm{~nm}$. All solutions were prepared fresh before the absorbance measurements.

\section{Agarose gel electrophoresis}

Solutions containing the CT-DNA and the $\mathrm{Hb}$ were incubated in the presence or absence of $\mathrm{H}_{2} \mathrm{O}_{2}$ at room temperature. Aliquots were taken and loaded onto $1 \%$ agarose gel. Electrophoresis was carried out in TBE buffer (1 M Tris base, $1 \mathrm{M}$ boric acid, and $0.05 \mathrm{M}$ $\mathrm{Na}_{2}$ EDTA, pH 8). The staining of gel was done by ethidium bromide. DNA Step Ladder (50 bp) was used in experiment that contained 17 fragments consisting of $50 \mathrm{bp}$ repeats from 50 to $500 \mathrm{bp}, 100 \mathrm{bp}$ repeats from 600 to $900 \mathrm{bp}$, and $1 \mathrm{~kb}$ repeats from 1 to $3 \mathrm{~kb}$.

\section{HOCl solution preparation.}

Stock solution of $\mathrm{HOCl}$ was prepared by mixing $1 \mathrm{ml}$ of sodium hypochlorite $(\mathrm{NaOCl})$ aqueous solution to $40 \mathrm{ml}$ of $154 \mathrm{mM} \mathrm{NaCl}$. The value of the $\mathrm{pH}$ was set at 3 by addition of $\mathrm{HCl}$ solution. To convert all convert active chlorine species to $\mathrm{OCl}^{-}$, the volume $40 \mu \mathrm{l}$ of $5 \mathrm{M} \mathrm{NaOH}$ was added and the concentration of $\mathrm{OCl}^{-}$was measured spectrophotometrically at $292 \mathrm{~nm}$ with molar extinction coefficient of $362 \mathrm{M}^{-1} \mathrm{~cm}^{-1}$. Since $\mathrm{HOCl}$ is very unstable, the stock solution was prepared just before the experiments, and stored on ice. All the dilutions were made from the stock solution by addition of appropriate volumes of $200 \mathrm{mM}$ phosphate buffer, $\mathrm{pH} \mathrm{7,2.}$

\section{CT-DNA solution preparation}

Stock DNA solutions were prepared by dissolving needed amount of DNA in $5 \mathrm{mM}$ tris(hydroxymethyl)aminomethane (Tris) buffer, mixed with $50 \mathrm{mM} \mathrm{NaCl}, \mathrm{pH}$ 7.2.

\section{Hemoglobin solution preparation}

$\mathrm{Hb}$ solution was prepared by dissolving $5 \mathrm{mg}$ of lyophilized powder in $10 \mathrm{~mL}$ of $200 \mathrm{mM}$ phosphate buffer $\mathrm{pH} 7.2$ to prepare $7.9 \mu \mathrm{M}$ solution. Further dilutions were made with the same phosphate buffer. 


\section{Heme solution preparation}

Heme stock solution was prepared in DMSO and kept in the dark at $4^{\circ} \mathrm{C}$. Diluted solutions were prepared by addition of a phosphate buffer, $\mathrm{pH}$ 7.2. The heme concentrations for each diluted solution was calculated by measuring absorbance at $404 \mathrm{~nm}$ using molar extinction coefficient of $170,000 \mathrm{M}^{-1} \mathrm{~cm}^{-1}$.

\section{RESULTS AND DISCUSSION}

The first spectra (Figure 1.) shows the changes in the spectra of $\mathrm{Hb}$ after addition of $40 \mu \mathrm{M} \mathrm{H}_{2} \mathrm{O}_{2}$. The visible spectrum of $\mathrm{Hb}$ shows a typical Soret absorbance peak at $405 \mathrm{~nm}$ that is indication of a ferric (III) heme. The absorption spectra of pure $\mathrm{Hb}$ exhibits several electronic bands located at $279 \mathrm{~nm}$ that are the result of phenyl group of tryptophan and tyrosine residues. Another band at $349 \mathrm{~nm}$ (e band) also known as Heme or Soret band is centered at $406 \mathrm{~nm}$ with two other bands at 540 and 570 nm (oxy band or Q-band) (Kristinsson, 2002).

It is well known that the appearance of strong Soret band (strongly allowed $\mathrm{p}-\mathrm{p}^{*}$ electron transition) at $406 \mathrm{~nm}$ in absorption spectra confirms $\mathrm{Hb}$ in its native form. This band is assigned to the heme group. Heme is deeply inserted in the hydrophobic pocket that is created from the protein's back bone through appropriate folding (Khan, Quigley, 2013).

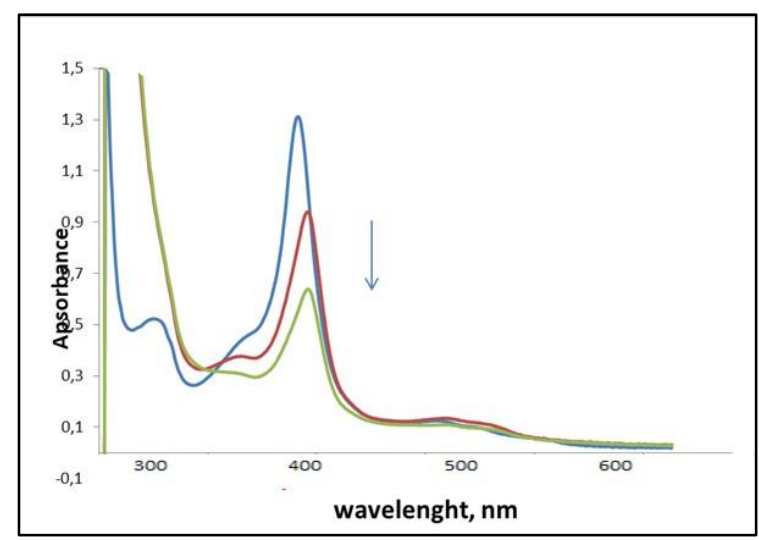

Figure1: The absorption spectra of $\mathrm{Hb}$ after addition of $40 \mu \mathrm{M}$ hydrogen peroxide in phosphate buffer, $\mathrm{pH}=7.2$

Any changes in Soret band are correlated to the changes in the heme microenvironment. After addition of $\mathrm{H}_{2} \mathrm{O}_{2}$ solution shift in Soret band and intensity was observed. Soret band shifted to $416 \mathrm{~nm}$, but absorbance intensity was lowered. This can be explained by formation of $\mathrm{Hb}-$ $\mathrm{Fe}(\mathrm{IV})=\mathrm{O}$ (Compound II) with a Soret band shifted to $418 \mathrm{~nm}$ and with less intensity due to the lower extinction coefficient. The solution of $\mathrm{Hb}$ was next incubated with $\mathrm{H}_{2} \mathrm{O}_{2} \mu \mathrm{M}$ where final concentration of $\mathrm{H}_{2} \mathrm{O}_{2}$ was $400 \mu \mathrm{M}$ and decrease in the absorbance was followed over time. (Figure 2).

Increasing concentration of $\mathrm{H}_{2} \mathrm{O}_{2}$ caused significant $\mathrm{Hb}$ heme decomposition that is confirmed by the loss of the intensity of the Soret peak. Incubation of $\mathrm{Hb}$ with 400 $\mu \mathrm{M}$ of $\mathrm{H}_{2} \mathrm{O}_{2}$ caused $70 \%$ decrease in the Soret band that after a time decayed indicating heme destruction due to the changes in the heme microenvironment that can be associated with protein aggregation and free iron release.
(Maitra, Andreana et al., 2011). As a control, the spectral changes of $\mathrm{Hb}$ in the presence of $\mathrm{HOCl}$ that can completely oxidize the heme structure of $\mathrm{Hb}$ were monitored over time.

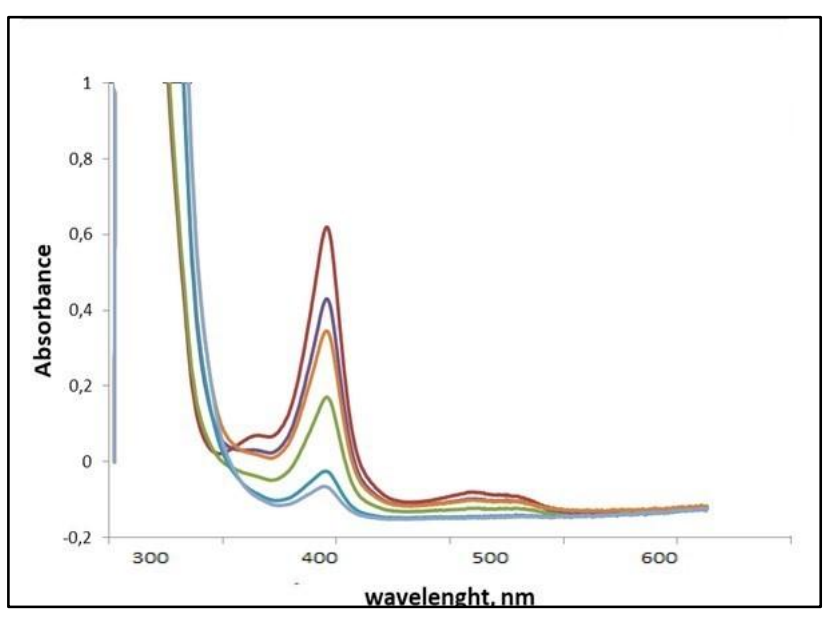

Figure2: The absorption spectra of $\mathrm{Hb}$ after addition of 400 $\mu \mathrm{M}$ hydrogen peroxide, in phosphate buffer, $\mathrm{pH}=7.2$

As expected, after addition on a increments of $\mathrm{HOCl}$ (10, $20,40,80 \mu \mathrm{M})$, almost complete flattening of the Soret peaks was observed after 10 minutes indicating complete destruction of the heme structure in $\mathrm{Hb}$ (Figure 3.)

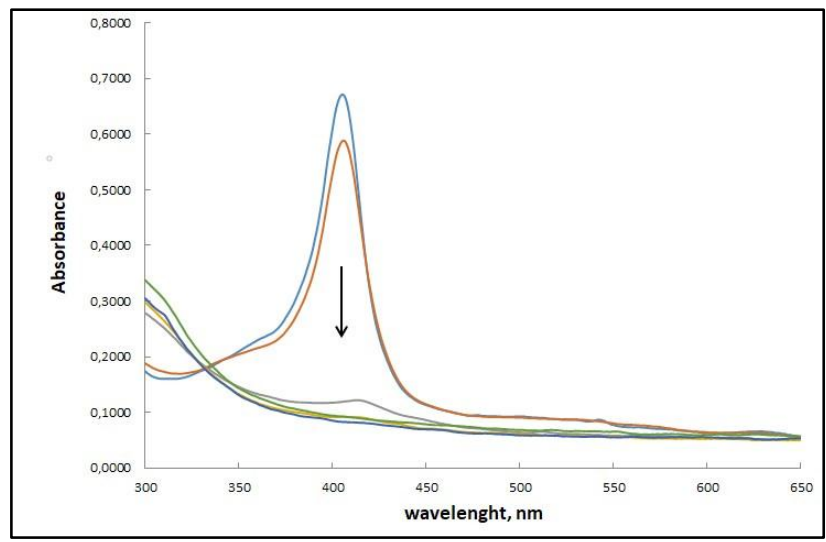

Figure 3: The absorption spectra of $\mathrm{Hb}$ obtained by titration with $\operatorname{HOCl}(5,10,20,40,80 \mu \mathrm{M})$

Comparing the obtained spectra with ones where $\mathrm{Hb}$ changes were observed in the presence of $\mathrm{H} 2 \mathrm{O} 2$, it is clear that $\mathrm{HOCl}$ directly affect heme environment without formation of Compound II. Apparently $\mathrm{HOCl}$ directly cleave the covalent bonds of heme protoporphyrine with protein structure of $\mathrm{Hb}$. Reaction of $\mathrm{H}_{2} \mathrm{O}_{2}$ with $\mathrm{Hb}$ follows peroxidase catalytic mechanism, thus giving the controlled decomposition of $\mathrm{Hb}$. The peroxidase activity of $\mathrm{Hb}$ promotes the formation of free radicals and oxidative stress that leads to the modification of biomolecules. Interactions of $\mathrm{Hb}$ with CT-DNA were tested in the presence of $\mathrm{H}_{2} \mathrm{O}_{2}$. Affinity of different forms of hemoglobin for doublestranded DNA was observed earlier (Tan, Cheng, Webber et al., 2005). More recently, a hemoprotein such as myeloperoxidase was detected to form MPO-DNA complexes in the process of NET-osis that is a characteristic response to severe inflammation. The 
exact nature of the complex and its role in the defense system is still unknown. Data clearly showed the interactions between the heme proteins and the DNA double helix. Structurally, it is necessary for heme moiety to change the conformation in order to allowed nucleobase oxidation. The presence of $\mathrm{H}_{2} \mathrm{O}_{2}$ near the heme center and its role as a substrate for the heme center could block and control heme-DNA interaction. Figure 4 shows the absorption spectra of $\mathrm{Hb}$ after addition of $40 \mu \mathrm{M}$, in phosphate buffer, $\mathrm{pH}=7.2$ with an addition of CT-DNA solution, $1 \mu \mathrm{M}$.

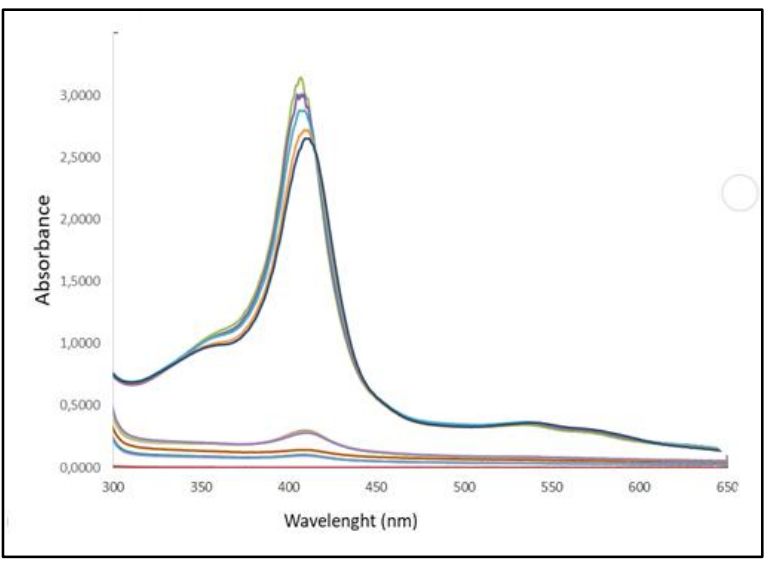

Figure 4. The absorption spectra of $\mathrm{Hb}$ after addition of 40 $\mu \mathrm{M}$ hydrogen peroxide, in phosphate buffer, $\mathrm{pH}=7.2$ with an addition of ctDNA solution, $1 \mu \mathrm{M}$.

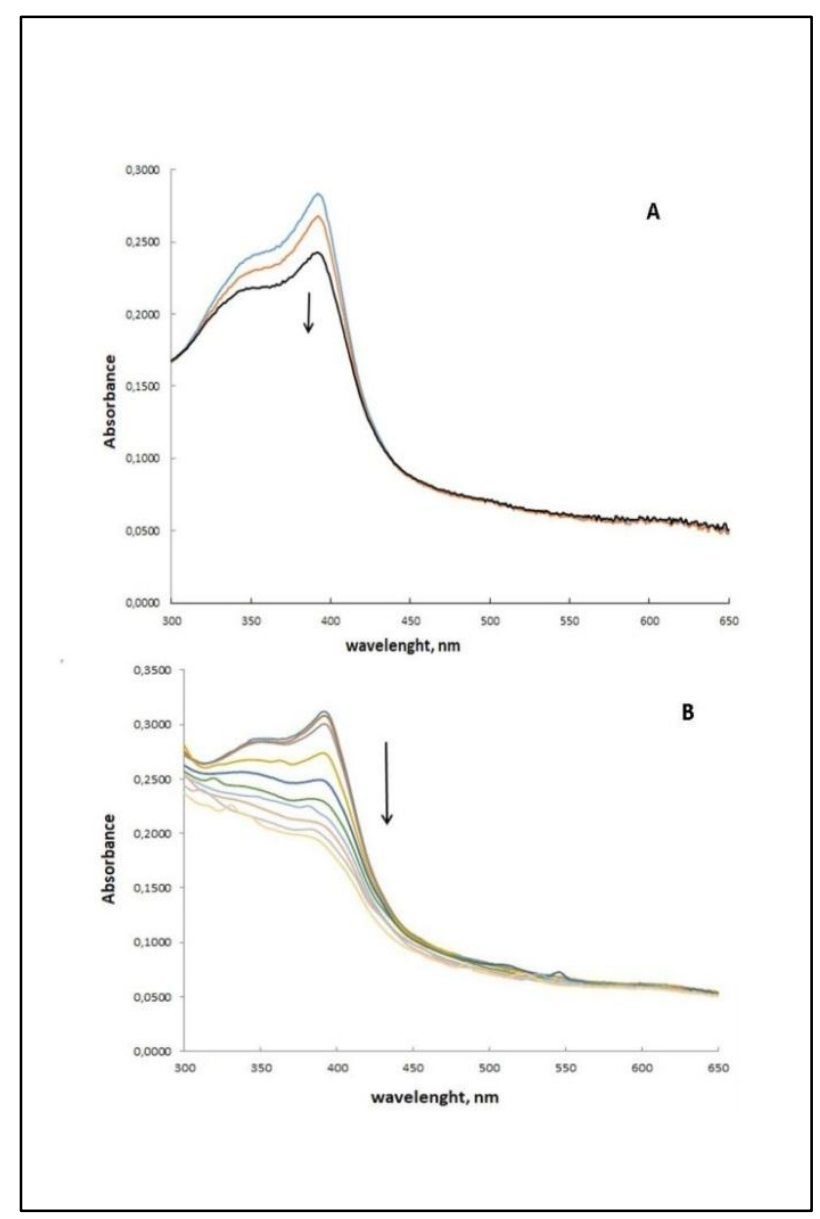

Figure 5. The absorption spectra of heme after addition of A.) $40 \mu \mathrm{M}$ hydrogen peroxide, and B.) $400 \mu \mathrm{M}$ hydrogen peroxide in phosphate buffer, $\mathrm{pH}=7.2$
Upon addition of low concentration of $\mathrm{H}_{2} \mathrm{O}_{2}$ shift in Soret absorbance was observed concomitant with Compound II formation, however, intensity of the Soret absorbance was not significantly lowered when compared with the Soret peak in the absence of ctDNA. This clearly demonstrates that the heme of $\mathrm{Hb}$ does not consume $\mathrm{H}_{2} \mathrm{O}_{2}$ completely due to the blocked heme site. Clearly, molecule of CT-DNA acted as an inhibitor of the peroxidase activity of $\mathrm{Hb}$. In order to test for the effect of the protein environment around heme structure, absorbance spectra of pure heme in the presence of $\mathrm{H}_{2} \mathrm{O}_{2}$ and $\mathrm{HOCl}$ were monitored and compared with those of Hb. (Figure5.)

Heme was completely decomposed upon addition of $\mathrm{HOCl}$ (data not shown). In reaction with $\mathrm{H}_{2} \mathrm{O}_{2}$ the decrease of the typical broad Soret band at $384 \mathrm{~nm}$ was observed. Addition of $400 \mu \mathrm{M}$ of $\mathrm{H}_{2} \mathrm{O}_{2}$ lowered the absorbance even more and Soret band disappearance was observed indicating the heme decomposition. Clearly, the protein environment close to the heme pocket of $\mathrm{Hb}$ plays a role in the peroxidase activity of $\mathrm{Hb}$.

Analysis of possible interactions between DNA and $\mathrm{Hb}$ that was incubated $\mathrm{H}_{2} \mathrm{O}_{2}$ was tested by agarose gel electrophoresis. (Figure 6).

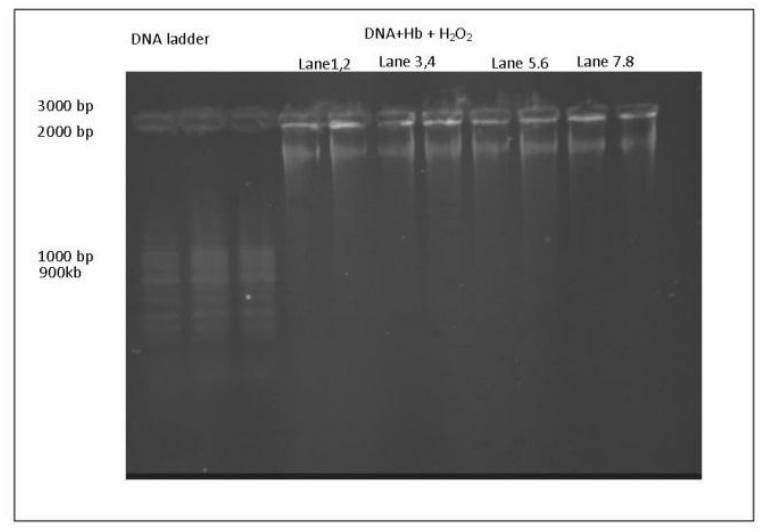

Figure 6 . Gel electrophoresis showing the intensity band of ctDNA in the absence and presence of $\mathrm{Hb}$ with various hydrogen peroxide concentrations (lane 1,2: 20 $\mu \mathrm{M}$, lane 3,4: $40 \mu \mathrm{M}$, lane 5.6.:100 $\mu \mathrm{M}$ and lane 7.,8: $400 \mu \mathrm{M})$

Lane 1 was untreated DNA alone, while lanes 2-4 ctDNA mixed with $\mathrm{Hb}$ and a different concentrations $\mathrm{H}_{2} \mathrm{O}_{2}(20,40,100$ and $400 \mu \mathrm{M})$. Heme inhibited ctDNA fragmentation regardless of $\mathrm{H}_{2} \mathrm{O}_{2}$ concentrations confirming the possible interactions with the $\mathrm{Hb}$ and inhibition of its peroxidase activity. Possible aggregation of protein with ct DNA could explain electrophoretic behavior. In any case, the peroxidation activity of $\mathrm{Hb}$ was apparently inhibited.

\section{CONCLUSIONS}

The destruction of hemoprotein heme in any extent is a process that can be extremely toxic for surrounding environment. Free iron accumulation has the ability to participate in the production of free radicals via Fenton reaction. $\mathrm{Hb}$ reaction with $\mathrm{H}_{2} \mathrm{O}_{2}$ that follows the 
peroxidase mechanism was not responsible for the complete heme destruction even at the higher concentration unlike highly reactive $\mathrm{HOCl}$. Rather, $\mathrm{Hb}$, in the presence of $\mathrm{H}_{2} \mathrm{O}_{2}$ showed formation of Compound II indicating classic peroxidase behavior. Mechanism of its peroxidase activity is highly controlled by the protein conformation rather than heme iron since heme alone was partially destructed by the increased in $\mathrm{H}_{2} \mathrm{O}_{2}$ concentration. CT-DNA partially blocked the peroxidase activity of $\mathrm{Hb}$, with a possible formation of heme-DNA adduct. These interconnecting mechanisms indicate the highly controlled environment even in the cases of elevated oxidative stress and might act in a protective manner. Further studies are needed to decipher the exact nature of these interactions.

\section{REFERENCES}

Beck, J. J. Chou, S. C. (2007). The Structural Diversity of Phthalides from the Apiaceae. Journal of Natural Product, 70 (5), 891-900.

Alayash, A. I., Patel, R. P., Cashon, R. E. (2001) Redox reactions of hemoglobin and myoglobin: biological and toxicological implications. Antioxidants \& Redox Signaling, 3(2), 313-327.

Khan, A. A., Quigley, J. G. (2013) Heme and FLVCRrelated transporter families SLC48 and SLC49. Molecular Aspects of Medicine, 34(2-3), 669-682.

Kristinsson, H. G. (2002) Acid-induced unfolding of flounder hemoglobin: evidence for a molten globular state with enhanced pro-oxidative activity. Journal of Agricultural and Food Chemistry, 50(26), 76697676.

Loose, M., Hudel, M., Zimmer, K. P. (2015) Pneumococcal hydrogen peroxide-induced stress signaling regulates inflammatory genes. Journal of Infectious Diseases, 211(2), 306-316.
Maitra, D., Byun, J., Andreana, P. R., Ibrahim Abdulhamid, I., Diamond, M., Saed, M. G., Pennathur, S., Abu-Soud, M. H. (2011) Reaction of hemoglobin with $\mathrm{HOCl}$ : mechanism of heme destruction and free iron release. Free Radicals in Biology and Medicine, 51(2), 374-38.

Nagababu, E., Chrest, F., Rifkind, J. (2003). Hydrogenperoxide-induced heme degradation in red blood cells: The protective roles of catalase and glutathione peroxidase. Biochimica et biophysica acta. 1620(13), 211-7.

Nagababu, E., Rifkind, J. M. (2004) Heme degradation by reactive oxygen species. Antioxidants \& Redox Signal, 6, 967-978.

Ong, W. Y., Halliwell, B. (204) Iron, Atherosclerosis, and Neurodegeneration: A Key Role for Cholesterol in Promoting Iron-Dependent Oxidative Damage? Annals of the New York Academy of Sciences, 1012, 51-64.

Pericone, C., Park, S., Imlay, J., Weiser, J. (2003) Factors Contributing to Hydrogen Peroxide Resistance in Streptococcus pneumoniae Include Pyruvate Oxidase (SpxB) and Avoidance of the Toxic Effects of the Fenton Reaction. Journal of Bacteriology, 185(23), 6815-6825.

Rifkind, J. M., Mohanty, J. G., Nagababu, E. (2015) The pathophysiology of extracellular hemoglobin associated with enhanced oxidative reactions. Frontiers in Physiology, 5, 500.

Schechter, A. N. (2008) Hemoglobin research and the origins of molecular medicine. Blood, 112, 39273938

Tan, W. B., Cheng, W., Webber, A., Bhambhani, A., Duff, M. R., Kumar, C. V., McLendon, G. L. (2005). Endonuclease-like activity of heme proteins. JBIC Journal of Biological Inorganic Chemistry, 10(7), 790-799.

Trinder, D., Fox, C., Vautier, G., Olynyk, J. K. (2002) Molecular pathogenesis of iron overload. Gut, 51, 290-295. 


\section{Summary/Sažetak}

Hemoglobin je protein sa hem centrom, tetramer koji se sastoji od četiri podgrupe proteinskih globina i četiri proteinske skupine hema. Najvažnija funkcija Hb je isporuka kisika iz pluća u periferno tkivo za stanični metabolizam. U uvjetima oksidativnog stresa mogući su načini uništavanja hema ili stvaranja drugih viših oksidativnih stanja. Cilj ove studije bio je istražiti aktivnost peroksidaze $\mathrm{Hb}$ s različitim koncentracijama vodikovog peroksida. Visoke koncentracije vodikovog peroksida preusmjerile su aktivnost peroksidaze $\mathrm{Hb}$ prema djelomičnom uništavanju Hb hema. Sam hem je degradiran, pokazujući da konformacija $\mathrm{Hb}$ i proteinsko okruženje štite $\mathrm{Hb}$ od distrukcije u prisustvu visoko povećane koncentracije vodikovog peroksida koja nastaje kao rezultat oksidativnog stresa. 